\title{
Concepts, benefits and perspectives of functional dairy food products
}

\author{
Liljana Anastasova $^{1 *}$, Tanja Petreska Ivanovska $^{2}$, Rumenka Petkovska $^{1}$, \\ Lidija Petrusevska-Tozi ${ }^{2}$ \\ ${ }^{1}$ Institute of Applied Chemistry and Pharmaceutical Analysis, Faculty of Pharmacy, \\ Ss. Cyril and Methodius University, Mother Theresa 47, 1000 Skopje, Republic of Macedonia \\ ${ }^{2}$ Institute of Applied Biochemistry, Faculty of Pharmacy, Ss. Cyril and Methodius University, \\ Mother Theresa 47, 10000 Skopje, Republic of Macedonia
}

Received: October 2018; Accepted: December 2018

\begin{abstract}
The rising awareness of the consumers towards the health benefits of food has resulted in the development of the so-called functional foods. These added value products which refer to prevention and/or therapeutic effects of food beyond its nutritional value, are especially useful for health improvement and reduction of medical care costs. The combination between health and nutrition and its potential to improve the quality of life has become one of the key attention points of consumers who are aware of and are seeking nutritional solutions to their health concerns.

Milk and dairy products have been used in human nutrition for thousands of years, providing important nutrients for the human body such as proteins, fats and calcium. It is now widely recognized that in addition to their basic nutritive role they also exert functional properties beneficial for human health, so the development of functional dairy products is one of the fastest growing areas in the dairy industry as well as one of the largest sectors in the global market of functional foods.

This review provides a brief overview of the health benefits and the natural functionality of dairy products as well as the challenges together with the future perspectives of their application as delivery vehicles for beneficial compounds to the human body.
\end{abstract}

Keywords: functional foods, milk, dairy products

\section{Introduction}

Functional foods (sometimes referred as physiologically functional foods, nutraceuticals, designer's foods or pharma foods) can be defined as those that provide the consumer with an identified health benefit above basic nutritional value (Bogue et al., 2017; Castillo et al., 2018; Playne et al., 2003). The concept of functional food was first introduced by Japanese scientists and later raised awareness for the need of such products in Europe and the United States. Today, there is much greater recognition that risk for disease development can be reduced and good health and well-being may be maintained through healthy lifestyle and diet. Ongoing support for the important role of foods such as fruits, vegetables, and whole grain cereals in disease prevention as well as dietary antioxidants and other phytoactive components from plants have helped the development of the functional food market, while the demographic and socioeconomic changes in population have raised the need for foods with added health benefits (Daliri and Lee, 2015). As a consequence, today's palette of functional products encompasses a wide variety of dairy-,

\footnotetext{
*ibogdanovska@ff.ukim.edu.mk
} 


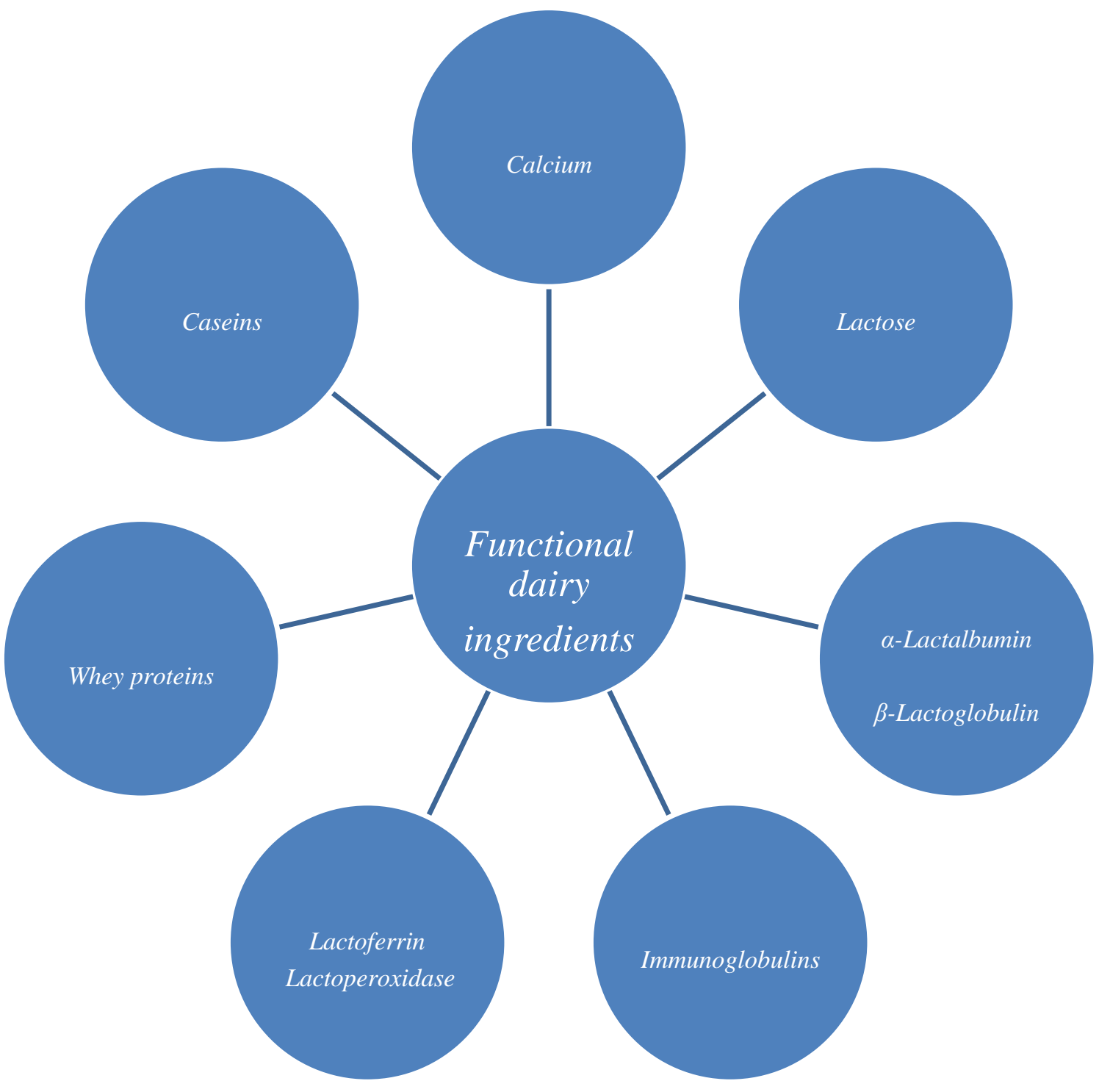

Fig. 1. Bioactive ingredients often used for enrichment/fortification of dairy products.

confectionery-, soft-drinks-, bakery- and baby-food products (Kotilainen et al., 2006; Menrad, 2003; Ortiz et al., 2017; Syro et al., 2018).

Milk and dairy products have been used as part of the human diet for thousands of years, playing an important role in the nutrition and development of human populations throughout the world (Ortiz et al., 2017). Also, milk and dairy-based ingredients have been widely used as components of many food products because of their contribution to critical characteristics such as unique flavor, desirable texture and natural appeal of the product (Allen Foegeding et al., 2010).

The health benefits of milk and dairy products have been known since medieval times (Bhat \& Bhat, 2011). These effects can be attributed to the numerous constituents of milk which exert favorable physiological functions and/or serve as precursors to biologically active substances in the human body (Fig. 1). Current scientific literature clearly indicates that dairy products consumption has positive influence on human health, reduces the risk of cardiovascular disease, atherosclerosis and improves the functions of the immune system as a whole (Davoodi et al., 2013; Elwood et al., 2010).

Functional dairy products represent of the largest segments in the functional food market, with hundreds of new products being produced each year, due to their wellestablished natural appeal (Turkmen et al., 2019). The principles in the development encompass incorporation of different "functional" substances or microorganisms ranging from probiotics and prebiotics, phytosterols, minerals, vitamins to bioactive peptides (Ortiz et al., 2017). Also, the production of innovative functional dairy 
products has focused on incorporating food byproducts as source of bioactive compounds, thereby reducing the waste in the food chain and offering new ways to diversify the production of dairy foods (Iriondo-DeHond et al., 2018). Regardless of the carrier used, dairy or nondairy, and bioactive compounds selected for the enrichment or fortification, the most important marker of consumer's acceptance is the sensory profile of functional foods. Hence, the development of functional foods beyond functional properties of the foods have to consider primary health concerns, consumer's familiarity with the concept of functional food and with the functional compounds, the nature of the carrier product, health effects, health claims helping consumers to make betterinformed food choice and sensory appeal as an extremely influencing factor (taste being a factor that directs consumer's choice and convenience as a basic requirement), packaging, shelf-life, and safety evaluation
(Annunziata and Vecchio, 2013). Products with "natural" matches between carriers and functional compounds seem to have the highest level of acceptance among consumers. To avoid a mismatch between consumer's needs and characteristics of new functional foods introduced in the market, great emphasis should be given in existing and future researches to consumer acceptance and preferences towards functional foods (Fig. 2). In this respect, acceptance for functional dairy products is increased due to certain bioactives which are naturally connected to these foods (probiotics, vitamins, minerals), especially among consumers with higher diet/health related knowledge, as well as with aging (Bimbo et al., 2017).

The purpose of this review is to give a brief overview of basic concepts of functional dairy products, to demonstrate their health benefits and to assess the trends in the development of novel dairy based functional products.

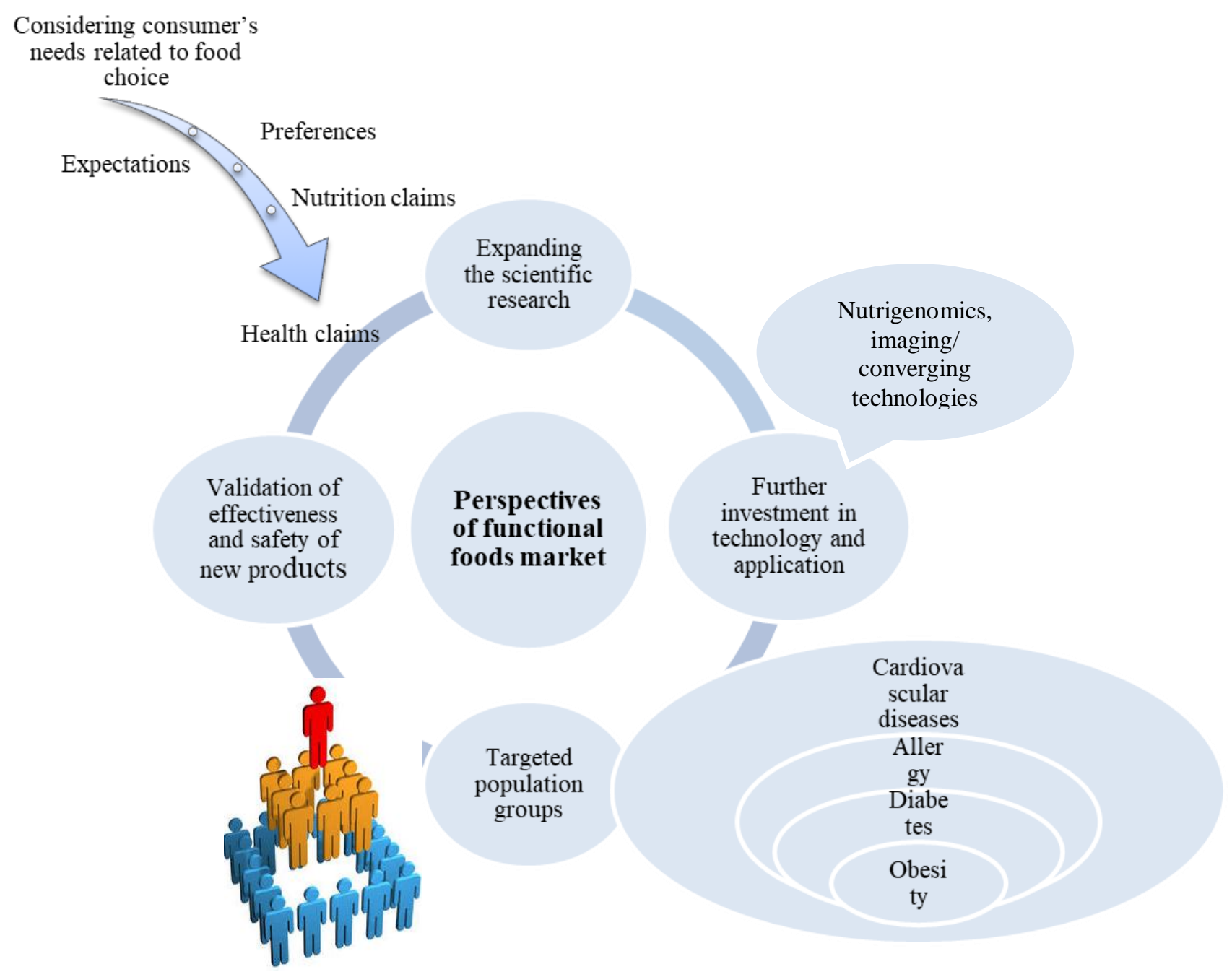

Fig. 2. Concepts for future trends in functional food market. 


\section{Functional dairy foods (products)}

\section{Milk}

Milk derived from all mammalian species is known as the "nature's best" food providing rich source of nutrients for the newborn, including protein, carbohydrate, lipids and minerals. Also, it is an available and rich source of these nutrients for the more mature consumer worldwide (Gantner et al., 2015; Haug et al., 2007; Playne et al., 2003; Visioli \& Strata, 2014). The high content of important minerals (calcium, magnesium, phosphorus) and vitamins (riboflavin and $\quad \beta$-carotene) as well the natural and bioavailable form in which these constituents are available to the human body puts milk in the category of physiologically functional foods (Erfanian et al., 2015; Playne et al., 2003).

The application of milk or dairy products as a vehicle for preparation of functional products is an excellent strategy that can lead to rapid improvement of the nutritional status of the population due to several advantages: milk is centrally processed and therefore quality control can be effectively implemented, it is widely consumed regularly in predictable amounts by people of different age groups and the cost is affordable by the target population. Milk is an excellent natural carrier for a wide range of added nutrients and their addition usually causes minimal changes in color, taste and appearance. Also, many studies have indicated that the stability and bioavailability of the added nutrients remains high (Alzate et al., 2010; Kaushik et al., 2014; Ocak \& Rajendram, 2013).

Due to the numerous benefits, milk has been the subject of many studies dealing with the preparation of more "active" functional products using probiotics, vitamins and minerals or other bioactive compounds. Among many functional dairy products, probably the most famous example is the addition of prebiotic substances and probiotics to milk (Bakr, 2015). Probiotics are defined as living microorganisms that when consumed in adequate quantities provide health benefits to the host (Hill et al., 2014). Lactic acid bacteria (LAB) and bifidobacteria are the most studied and widely employed probiotics because they are normal constituents of intestinal microflora and have a long history of safe applications within the food industry. The use of milk is directly related to milk composition, which is a better matrix for probiotic bacteria growth than dietary supplements. Using probiotics in nutraceuticals, such as in capsules may lead to a reduction in functional efficacy due to the exclusion of the potential synergistic effect of the food. Originally, probiotic delivery was consistently associated with foods, particularly dairy foods help to buffer the probiotics through gastrointestinal tract and support their colonization (Ranadheera et al., 2010). Further, the metabolic activity of the probiotics in milk can result in formation of another interesting group of bioactive compounds called probioactives. Such compounds, for example, are specifically released by the hydrolysis of milk's casein and appear only in fermented foods but not in dietary supplements. Therefore, milk and dairy products should be used as a vehicle for probiotics instead of supplements (Champagne et al., 2018).

The favorable effects of other types of functional milks, such as vitamin- and mineral enriched milk have been evaluated by researchers in different studies. These products include folic acid fortified milk for better absorption of folic acid (Mitsukutchi et al., 2017). Calcium and vitamin D fortified milk along with magnesium and zinc improves vitamin D status, lowers parathyroid hormone levels and reduces bone turn over (Bonjour et al., 2009; Kruger et al., 2010). Calcium in the form of calcium caseinate-phosphate complex in milk is readily released during digestion, making its bioavailability high. Since good bone health can be achieved through appropriate diet and active lifestyle, the usage of calcium-fortified milk in every day nutrition could protect from osteoporosis and bone fractures in later stages of life (Rajasekaran \& Kalaivani, 2013).

Iron-fortified milks have been designed to address the issue of anemia and studies have shown that this type of product improves anemic status thus it is a favorable approach in reducing micronutrient deficiencies in young and preschool children (Rajasekaran \& Kalaivani, 2013; Sazaval et al., 2010). Selenium-enriched milk can be used to improve selenium status in humans and at the same time reduce the risk of developing cancer (Alzate et al., 2010; Hu et al., 2010).

Dairy proteins from milk and their properties have been intensively studied. They play important nutritional role and supply the body with essential amino acids and organic nitrogen and at the same time are rich source of biologically active peptides. They possess beneficial properties, but remain inactive within the sequence of the parent protein. Once released after enzyme hydrolysis, the peptides show radical scavenging, metal ion complexation properties and ability to inhibit lipid peroxidation. Lactoferin from milk has been reported to inhibit intestinal tumors because of its apoptotic activity and the ability to modulate carcinogen- metabolizing enzymes (Pereira et al., 2016). On the other hand, intact milk proteins possess nutraceutical properties that enable their use as carriers of vitamins, minerals and fatty acids in addition to their immunomodulatory, anti-cancer, hypotensive and antibacterial properties (Mohanthy et al., 2014).

\section{Fermented dairy products}

Fermented dairy products hold a long tradition and contribution to the nutrition of many societies and cultures worldwide and have been used to enhance intestinal health from ancient times. Even before scientific studies documented this benefit, fermented milk products were 
used to alleviate diarrhea caused by infection of pathogenic bacteria (Bashali et al., 2014).

The process of fermentation enables preservation of food as well as transformation of the raw material into a new product with unique sensorial properties (Bashali et al., 2014). During fermentation, the enzymatic activity of the raw material and the metabolic activity of the microorganisms can change the nutritive and bioactive properties of the food matrix resulting in beneficial effect for human health. Additionally, fermentation can result in removal of toxic or undesirable food constituents (Marco et al., 2017).

Fermented dairy products often contain compounds that are not present in regular milk such as exopolisaccharides (ex. kefiran in kefir) and natural enrichments including increased vitamin $\mathrm{B}_{12}, \mathrm{~K}_{2}$, folate and riboflavin content (Hugenholz, 2013). Furthermore, they usually possess $\beta-$ galactosidase activity and reduced lactose content compared to milk, making them potentially suitable for people suffering from lactose intolerance.

Many scientific studies have confirmed that natural fermented dairy products may possess antihypertensive effects, enhance systemic immunity and lower cholesterol and blood pressure. They may also serve as rich source of bioactive peptides released through fermentation by proteolytic cultures and have been linked to many potential health benefits to the endocrine, digestive, cardiovascular, and immune and nervous system (Marsh et al., 2014).

\section{Yogurt}

Yogurt is a fermented dairy product usually obtained as a result of the fermentation process of milk by lactic acid bacteria such as Streptococcus thermophyllus and Lactobacillus bulgaricus. It possesses added health benefits over its parent product, milk and has provided the human body with nutrients and bioactive compounds long before the concept of functional food was known. The clear association between the consumption of yogurt and good health has resulted in an increased consumption of this product in recent years.

Yogurt, as nearly complete food, is an excellent source of protein, fat, essential vitamins and minerals such as calcium, magnesium, zinc, iodine and potassium. The fermentation process may increase the bioavailability of vitamin $\mathrm{B}_{12}$, calcium and magnesium as well as proteins and peptides (especially in Greek style yogurt). In this manner, it can be considered as an ideal product for children and elderly who need to maintain their skeletal mass (Fernandez \& Marette, 2017). Human studies have clinically demonstrated that yogurt consumption in lactose-intolerant individuals increases lactase activity in the small intestine, in addition to improved lactose tolerance, immune enhancement, and prevention of gastrointestinal disorders (Prentice, 2014; Savaiano, 2014).
As a probiotic carrier food, it can deliver significant amounts of probiotic bacteria in the body. Probiotics and prebiotics found in yogurt have been reported to have many beneficial effects such as weight reduction, cholesterol reduction and positive effects on overall cardiovascular health including hypertension (Gahruie et al., 2015).

In general, yogurt is the most preferring to be used as a base product for supplementation with a whole spectrum of bioactive compounds apart from the probiotics. Yogurts can be fortified/enriched with cereal grains, different seeds, fresh and dried fruits and their consumption is associated with numerous health and nutritional benefits (Guine \& De Lemos, 2018). For example, the combination yogurt-fruit is offering nutrient dense and lower-energy alternatives in place of typical nutrient-poor snacks such as desserts and cakes; however, the beneficial effects should be confirmed in larger clinical studies (Sayon-Orea et al., 2015).

Studies comparing different food matrices showed that the matrix of yogurt is an appropriate carrier for plant sterols and stanols providing cholesterol-lowering efficiency (Algorta-Pineda et al., 2005; Clifton et al., 2004; Hyun et al., 2005; Mensink et al., 2002; Volpe et al., 2001). Based on the evidence, national and international guidelines recommend functional foods with added plant sterols and stanols as part of a dietary prevention strategy for promotion of cardiovascular health, in particular, management of hypercholesterolemia. It has been accepted that daily intake of $2 \mathrm{~g}$ plant sterols and stanols lowers plasma LDL-cholesterol concentrations by a median of $10 \%$ following a 4-week supplementation protocol. Therefore, plant sterols and stanols are granted a health claim regarding their beneficial effects, and functional foods supplied with these agents are offered to consumers in many countries. Since yogurt already has unique properties that make it an important component of a healthy and balanced diet, addition of plant sterols and stanols into yogurt provides the development of a new functional food that increases the benefit for consumers (Buyuktuncer, 2017).

Yogurt has shown great potential to be utilized as nutritional intervention for people living with HIV. It is a palatable product that contains good quality protein, essential micronutrients and can enhance a protective intestinal microbiome. Yogurt can significantly improve the protein and nutrient density of low-quality and lowquantity diets; this is required for optimal immune function. Yogurt can be locally produced in resource-poor regions and is accepted in regions most affected by the HIV epidemic. In addition, it can serve as a vector for additional micronutrient, probiotic, and prebiotic supplementation, which have been shown to reduce the sequelae of a pro-inflammatory state and microbial translocation in HIV (Hummelen \& Hemsworth, 2017). 


\section{Kefir}

Kefir is a self-carbonated, slightly foamy viscous beverage, with a uniform elastic consistency and sour, acidic, and slightly alcoholic flavor. It is produced by the actions of the microflora encased in the kefir grain on the carbohydrates in the milk. This fermented milk beverage is regarded as an easily digested product and esteemed for its nutritional value (Bashali et al., 2014). Containing bacterial species known for probiotic properties, it has long been popular in Eastern Europe for its health benefits where it is routinely administered to patients in hospitals and recommended to infants (Nielsen et al., 2014). Kefir has been shown to positively influence GIT, stimulate the immune system and has anti-inflammatory and anticarcinogenic effects, albeit not through clinical trials (Oliveira Leite et al., 2013).

The microbial profile of this beverage consists of around 30 species of $\mathrm{LAB}$ and yeast classifying kefir as major probiotic source (Ahmed et al., 2013; Kolakowski et al., 2012; Yang et al., 2010). The yeasts have been shown to enhance aggregation and adhesion of LAB to the epithelial cells and straighten their gastrointestinal tolerance. The reported probiotic activity of kefir also includes protection from toxins (Farnworth, 2003; Xie et al., 2012). The kefiran component of kefir may also act as a prebiotic, supporting the growth and expression of known probiotic bacteria (Nielsen et al., 2014).

It affects the blood pressure through ACE-inhibition and exhibits immunomodulatory effects which may lead to reducing allergic responses in food allergy (Nielsen et al., 2014). However, studies on the benefits of kefir on cholesterol reduction have shown mixed effects (Vujicic et al., 1992).

Kefir and kefir fractions have been shown to be effective in killing cancer cells in vitro and in slowing cancer growth in vivo (Shiomi et al., 1982). According to one study, more than one third of patients with cancer use complementary and alternative medicine and the use of kefir by patients undergoing chemotherapy to help them alleviate GIT side effects have increased (Can et al., 2009).

Apart from preparation of functional kefir enriched with dietary fibers (Goncu et al., 2017; Simsek et al., 2017), the scientific literature is relatively poor in studies dealing with the preparation of other types of functional kefir drinks.

\section{Ayran}

Ayran (drinking yogurt) is a fermented traditional product prepared by addition of water to homemade yogurt or by addition of Streptococcus thermophillus and Lactobacillus delbrueckii ssp. bulgaricus to industrially produced milk, according to the Turkish Food Codex (TFC, 2009). It is an easily digestible and highly valued drink with high vitamin and calcium content, especially used as cold refreshment during the summer. The ayran has been subjected to many investigations in order to make this product more "functional", healthier or with greater antioxidant capacity. However, the main technological problem is ayran's instability during storage. Thus, the addition of stabilizers must be considered (Yilmaz et al., 2015). The incorporation of inulin or pectin in the ayran has produced a functional drink with higher content of aroma components and higher antioxidant activity (Najgebauer-Lejko \& Sady, 2015; Kök-Taş \& Güzel-Seydim, 2010). Ayran has been successfully used as a vehicle for delivery of cocoa hull waste phenolics in the form of lipozomes (Altin et al., 2018). Also, efforts have been made to add probiotic and prebiotics to make a more functional drink. In the study performed by Petreska Ivanovska et al. (2018), new probiotic/synbiotic drink enriched with Lacobacillus casei 01 and oligofructose - enriched inulin was developed. The obtained samples enriched with synbiotic microparticles containing L. casei 01 and oligofructose-enriched inulin had the main advantage in terms of probiotic survival and increased production of lactic, acetic and propionic acid. The newly developed product gained functional properties, while retaining the quality of conventional ayran with the possibility to be offered to consumers as a part of a healthy diet. Ayran supplied with the same symbiotic microparticles has provided anti-inflammatory activity in trinitrobenzene sulfonic acid-induced model of rat colitis indicating one potential approach in prevention and treatment of inflammatory bowel diseases (Petreska Ivanovska et al., 2017).

\section{Cheese}

Cheese is a dairy product rich in nutrients such as proteins, peptides, different types of fatty acids, several vitamins and essential minerals such as calcium. Being very nutritious it has a long history in the human diet. The high content of fat and protein makes cheese energy-rich and nutritious food for all age groups. Nowadays, a wide variety of cheese products from Cheddar to Mozzarella are produced worldwide and the trend is continuously increasing (Exposito et al., 2016).

Cheese is a rich source of dairy fat. Kratz et al. (2013), reviewing the effects of food rich in fat on human health, summarized various studies demonstrating that dairy fat consumption can provide better metabolic health and may protect against metabolic dysfunction. In addition, cheese is an excellent source of minerals, especially calcium and phosphorus. The casein - calcium phosphate of cheese shows high mineralization potential on teeth enamel, so the EFSA has supported the consumption of cheese as an anti-caries measure (EFSA, 2008). Cheese proteins are one of the most important nutrients, responsible for nutritional, physicochemical, functional and sensory aspects of cheese. The bioactive peptides exhibit different physiological effects such as anti-oxidative action, modulation of gastric function as well as lowering the blood pressure (Exposito et al., 
2016). Lactoferin, a biologically active peptide which undergoes denaturation in sterilized milk or yogurt, is abundant in cheese a detectable range and represents an alternative source of biologically active lactoferin. An interesting example are the Italian hard cooked cheese types such as Parmigiano Reggiano and Grana Padano because according to their composition they can be considered se "functional foods". During cheese ripening (enzyme-modified cheese process) bioactive peptides of physiological importance may be produced, such as opioid peptides, ACE-inhibitory peptides, casein peptides with immunomodulatory action or caseinophosphopeptides which may function as mineral careers (Summer et al., 2017).

Cheese has been used as a suitable platform for delivery of probiotics. According to certain studies the combination of hypocaloric diet and probiotic cheese could help reduce body mass index, arterial blood pressure and the risk of metabolic syndrome in obese patients with hypertension (Castro et al., 2015; Sharafedtinov et al., 2013). In order to increase mineral intake, cheese has been fortified with iron-enriched yeast and the study conducted in 32 young women indicated that these type of functional product shows similar iron bioavailability when compared to the iron bioavailability from ferrous sulphate (Sabatier et al., 2017). Also, cheese was fortified with vitamin D using protein emulsions as delivery systems and increased retention of this vitamin was achieved in cheddar cheese (Tippets et al., 2012). Cheese can be relatively easily fortified with vitamin $\mathrm{D}_{3}$ to provide up to $100 \%$ daily value in the diet, as it has a higher milk fat content than liquid milk, which aids inclusion of fat-soluble vitamins (Ganesan et al., 2011). Standardized cow's milk (fat $3 \mathrm{~g} / 100 \mathrm{~g}$ ) was used to manufacture Feta cheese fortified with 40,60 and $80 \mathrm{mg}$ of iron $/ \mathrm{kg}$ cheese using ferrous sulphate $\left(\mathrm{FeSO}_{4}\right)$, ferric chloride $\left(\mathrm{FeCl}_{3}\right)$, ferric pyrophosphate $\left(\mathrm{Fe}_{4}\left(\mathrm{P}_{2} \mathrm{O}_{7}\right)_{3}\right)$ and microencapsulated ferrous sulphate. Chemical composition and sensory characteristics of fortified cheeses were determined after 60 days of ripening and the best quality was found in cheeses fortified with $40 \mathrm{mg} / \mathrm{kg}$ of microencapsulated ferrous sulphate. Cheese has been used as a matrix for incorporating natural and synthetic antioxidants (Alenisan et al., 2017).

\section{Ice cream}

Ice cream can be defined as frozen complex dairy food system containing ice crystals, air cells, polysaccharides, proteins and minerals, especially calcium, but also sodium and potassium (Goff, 2008). Frozen dairy desserts such as ice cream, adapt most readily to nutrient fortification and inclusion of nutraceuticals, thus they can be used as adequate carriers of nutraceuticals because of their low storage temperature, ability to stabilize ingredients as well as the popularity among consumers (Goraya and Bajwa, 2015). Current advances in the development of the ice cream technology have resulted in preparation of functional ice cream, product enriched with bioactive compounds or probiotics.

The nutrient composition and energy value of ice cream is related to the food value of the products from which it is made, but regardless of the mix, ice cream is an excellent source of energy and an ideal substrate for the proliferation of probiotics (Etarevi Evive et al., 2017; Soukulis et al., 2014). In order to provide health benefits, ice cream has been enriched with insoluble dietary fiber, natural antioxidants and fruits and fruit-based products which represent an alternative strategy for increase of the phenolic content of the product. As for milk and milk products, ice cream and other frozen dairy desserts can be used as excellent sources of inorganic minerals and watersoluble vitamins (Marshall et al., 2003). Ice cream is considered a good source of calcium $(836 \mathrm{mg} / \mathrm{kg})$ and as an excellent vehicle for calcium administration to different target groups (van der Hee et al., 2009; Ferrar et al., 2011).

Despite the development of several types of functional ice cream products, there is scarce evidence for the health benefits from clinical trials. Also, the potential of novel strategies for incorporation of different bioactive compounds to ice cream should be thoroughly investigated.

\section{Conclusion}

The development and usage of functional dairy products offers numerous benefits to the consumers and represents an important strategy to improve the health and nutritional status of millions of people. These products should be consumed as a part of the healthy diet throughout all life periods especially during childhood and adolescence and in elderly people. In future, their efficacy and health promoting effects must be confirmed in larger clinical studies and collaboration between food producers and scientists must be accomplished. In addition, further understanding of the functional properties of many dairy ingredients would allow food technologists to utilize their potential contribution to product characteristics in order to develop novel functional products. General interest in health and increased consumer awareness as well as perceived selfefficacy has to contribute to shaping the acceptance of functional food products, while the creativity of food technology should further advance the development of food products that can support optimum health.

\section{References}

Ahmed, Z., Wang, Y., Ahmad, A., Tariq Khan, S., Nisa, M., Ahmad, H., Afreen, A., 2013. Kefir and health: a contemporary perspective. Crit. Rev. Food Sci. Nutr. 53, 422-434. Available at: https://doi.org/10.1080/10408398.2010.540360. 
Allen Foegeding, F., Cakir, E., Koc, E., 2010. Using dairy igredients to alter texture of foods: implications based on oral processing considerations. Int. Dairy J. 29, 562-570. Available at: https://doi.org/10.1016/j.idairyj.2009.12.013.

Algorta-Pineda, J., Chinchetruranedo, M.J., Aguirre, J., Francisko Terreros, S., 2005. Hypoholesterolemic effectiveness of a yogurt containing plant stanol esters. Rev. Clin. Esp. 205, 63-66 (abstract).

Alenisan, M., Allgatan, H., Tolbach L.S., Shori, A., 2017. Antioxidant properties of dairy products fortified with natural additives: a review. J. Assoc. Arab Univ. Basic Appl. Sci. 24, 101-106. Available at: https://doi.org/10.1016/j.jaubas.2017.05.001.

Altin, G., Gültekin-Özgüven, M., Ozcelik, B., 2018. Liposomal dispersion and powder systems for delivery of cocoa hull waste phenolics via Ayran (Drinking Yoghurt): Comparative studies on in-vitro bioaccessibility and antioxidant capacity. Food Hydrocoll. 81, 364-370. Available at: https://doi.org/10.1016/j.foodhyd.2018.02.051.

Alzate, A., Perez-Conde, M.C., Gutierrez, A.M., Camara, C. 2010. Selenium-enriched fermented milk: a suitable diary product to improve selenium intake in humans. Int. Dairy J. 20, 761-769. Available at: https://doi.org/10.1016/j.idairyj.2010.05.007.

Annunzita, A., Vecchio, R., 2013. Consumer perception of functional foods: A conjoint analysis with probiotics. Food Qual. Prefer. 28, 348-355. Available at: https://doi.org/10.1016/j.foodqual.2012.10.009.

Bakr, S.A., 2015. The potential applications of probiotics and prebiotics on dairy and non-dairy foods focusing on viability during storage. Biocat. Agricult. Biotechnolog. 4, 423-431. Available at: https://doi.org/10.1016/j.bcab.2015.09.010.

Baschali, A., Tsakilidou, E., Kyriacou, A., Karvasiloglou, N., Matalas, A., 2017. Traditional low-alchocolic and nonalchocolic fermented beverages consumed in European countries: a neglected food group. Nutr. Res. Rev. 30, 124. Available at: https://doi.org/10.1017/S0954422416000202.

Bhat, Z.F., Bhat, H., 2011. Milk and dairy products as functional foods: a review. Int. J. Dairy Sci. 6, 1-12. Available at: https://doi.org/10.3923/ijds.2011.1.12.

Bimbo, F., Bonnano, A., Noclla, G., Viscecchia, R., Nardone, G., Devitiis, B., Carlucci, D., 2017. Consumer's acceptance and preferences for nutrition-modified and functional dairy products: a systematic review. Appetite 113, 141-154. Available at:

https://doi.org/10.1016/j.appet.2017.02.031.

Bogue, J., Collins, O., Troj, A.J., 2017. Market analysis and concept development of new functional foods, in: Bagchi, D., Nair, S., (Eds.), Developing new functional food and nutraceutical products. Academic press, San Diego, pp. 29-45. Available at: https://doi.org/10.1016/B978-0-12802780-6.00002-X.

Bonjour J.P., Benoit, V., Pourchaire, O., Ferry, M., Rousseau B., Souberbielle, J.C., 2009. Inhibition of markers of bone resorbtion by consumption of vitamin $\mathrm{D}$ and calcium fortified soft plain cheese by institutionalized elderly women. Br. J. Nutr. 102, 962-966. Available at: https://doi.org/10.1017/S0007114509371743.

Buyuktuncer, Z., 2017. Yogurt with plant sterols and stanols, in: Shah, P.N. (Ed.), Yogurt in Health and disease prevention.
Academic press, Elsevier, London, pp.151-163. Available at: https://doi.org/10.1016/B978-0-12-805134-4.00008-0.

Can, C., Topuz, E., Derin, D., Durna Z., Aydinar, A., 2009. Effect of kefir on the quality of life of patients being treated for colorectal cancer. Oncol. Nurs. Forum 36, E335-E342. Available at: https://doi.org/10.1188/09.

Castillo, M.D., Irionodo-Dehond, M., Martirosyan, D.M., 2018. Are functional foods essential for sustainable health? Ann. Nutr. Food Sci. 2, 1-4.

Castro, J.M., Tornadijo, M.E., Fresno, J.M., Sandoval, H., 2014. Biocheese; a food probiotic carrier. BioMed Res. Int. 2015, Available at: https://doi.org/10.1155/2015/723056.

Champagne, C.P., Gomez da Cruz, A., Daga, M., 2018. Strategies to improve functionality of probiotics in supplements and in foods. Curr. Opin. Food Sci. 22, 160166. Available at: https://doi.org/10.1016/j.cofs.2018.04.008.

Clifton, P.M., Noakes, M., Sullivan, D., Erichesen, N., Ross, D., Annison, G., Fassoulakis, A., Cehun, M., Nestel, P., 2004. Cholesterol-lowering effects of plant sterols esters differ in milk, yogurt, bread and cereal. Eur. J. Clin. Nutr. 58, 503-509. Available at: https://doi.org/10.1038/sj.ejcn.1601837.

Davoodi, H., Esmaeili, S., Mortazavian A.M., 2013. Effects of milk and milk products consumption on cancer: a review. Comprehen. Rev. Food Sci. Technol. 12, 249-264. Available at: https://doi.org/10.1111/1541-4337.12011.

Daliri, E., Lee, B., 2015. Current trends and future perspectives on functional foods and nutraceuticals, in: Liong, M., Steinbuchel, A. (Eds.), Beneficial microorganisms in Food and nutraceuticals. Springer International Publishing, Switzerland, pp. 221-244. Available at: https://doi.org/10.1007/978-3-319-23177-8_10.

Elwood, P.C., Pickering, J.E., Givens, D., Gallacher, J.E., 2010. The consumption of milk and dairy foods and the incidence of vascular disease and diabetes: an overview of the evidence. Lipids, 45, 925-939. Available at: https://doi.org/10.1007/s11745-010-3412-5.

Erfanian, A., Mirhosseini, H., Rasti, B., Hair-Bejo, M., Bin Mustafa, S., Manap, M., Y., A., 2015. Absorbtion and bioavailability of nano-sized reduced calcium citrate fortified milk powder in ovariectomized and ovariectomized-osteoporosis rats. J. Agricul. Food Chem. 63, 5795-5804. Available at: https://doi.org/10.1021/acs.jafc.5b01468.

Etarevi Evive, S., Huo, G., Oamen Igene, J., Bian, X., 2017. Some current applications, limitations and future perspectives of lactic acid bacteria as probiotics. Food Nutr. Res. 61, 1318034. Available at: https://doi.org/10.1080/16546628.2017.1318034.

European Food Safety Agency, 2008. Scientific substantiation of a health claim pursuant related to dairy products (milk and cheese) and dental health to article 14 of regulation (EC), No 1924/20061. EFSA J. 787, 1-9.

Farnworth, E.R., Mainville, I., 2003. Kefir: a fermented milk product, in Farnworth, E. (Ed) Handbook of fermented functional foods. Taylor \& Francis CRC Press, Boca Raton, pp: 78-111. Available at: https://doi.org/10.1201/9780203009727.

Ferrar, L., Van der Hee, R.M., Berry, E., Watson, C., Miret, S., Wilkinson, J., Bradburn, M., Eastell, R., 2011. Effects of calcium-fortified ice cream on markers of bone health. Osteoporosis Int. 22, 2721-2731. Available at: 
https://doi.org/10.1007/s00198-010-1513-x.

Fernandez, M.A., Marette, A., 2017. Potential health benefits of combining yogurt and fruit based on their probiotic and prebiotic properties. Adv. Nutr. 8, 155S-164S. Available at: https://doi.org/10.3945/an.115.011114.

Gahruie, H.H., Eskandari, H.M., Mesbahi, G., Hanifpour, M.A., 2015. Scientific and technical aspects of yogurt fortification: a review. Food Sci. Hum. Well. 4, 1-8. Available at: https://doi.org/10.1016/j.fshw.2015.03.002.

Ganesan, B., Brothersen, C., McManon, D.J., 2011. Fortification of Cheddar cheese with vitamin D does not alter cheese flavor perception. J. Dairy Sci. 94, 3708-3714. Available at: https://doi.org/10.3168/jds.2010-4020.

Gantner, V., Mijic, P., Baban, M., Skrtic, Z., Turalija, A., 2015. The overall and fat composition of milk of various species. Mljekarstvo 65, 223-231. Available at: https://doi.org/10.15567/mljekarstvo.2015.0401.

Goraya, K.R., Bajwa, U., 2015. Enhansing the functional properties and nutritional quality of ice cream with processesd amla (Indian gooseberry). J. Food Sci.Technol. 52, 7861-7871. Available at: https://doi.org/10.1007/s13197-015-1877-1.

Goof, H.D., 2008. 65 years of ice cream history. Int. Dairy J. 18, 754-8. Available at: http://agris.fao.org/agrissearch/search.do?recordID=US201300905617.

Goncu, B., Celikel, A., Guler-Akin, M., Serdar Akin, M., 2017. Some properties of kefir enriched with apple and lemon fiber. Mljekarstvo 67, 208-216. Available at: https://doi.org/10.15567/mljekarstvo.2017.0305.

Guine, R., Lemos, E.T., 2018. Development of new dairy products with functional ingredients. J. Cul. Sci. Technol. Available at: https://doi.org/10.1080/15428052.2018.1552901.

Haug, A., Hostmark, A., Harstad, O., 2007. Bovine milk in human nutrition - a review. Lipids Helth Dis. 6:25. Available at: https://doi.org/10.1186/1476-511X-6-25.

Hill, C., Guarner, F., Reid, G., Gibson, G.R., Merenstein, D., Pot, B., Sander, M.E., 2014. The international scientific assoiaciation for probiotics and prebiotics consensus statement on the scope and appropriate use of the term probiotic. Nat. Rev. Gastoent. Hep. 11, 506-514. Available at: https://doi.org/10.1038/nrgastro.2014.66.

Hugenholtz, J., 2013. Traditional biotechnology for new products and beverages. Curr. Opin. Biotechnol. 24, 155-9. Available at: https://doi.org/10.1016/j.copbio.2013.01.001.

Hu, Y., McIntosh, G.H., Le Leu, R.K., 2010. Selenium-enriched milk proteins and selenium yeast affects selenoprotein activity and expression differently in mouse colon. Br. J. Nutr. 104, 17-23. Available at: https://doi.org/10.1017/S0007114510000309.

Hummelen, R., Hemsworth, J., 2017. Yogurt, and pre- and probiotics to reduce the progression of HIV, in: Shah, P.N. (Ed.), Yogurt in Health and disease prevention. Academic press, Elsevier, London, pp.151-163. Available at: https://doi.org/10.1016/B978-0-12-805134-4.00008-0.

Hyun, Y.J., Kim, O.Y., Kang, J.B., Lee, J.H., Jang, Y., Liponkoski, L., Salo, P., 2005. Plant stanol esters in low-fat yogurt reduces total and low-density lipoprotein cholesterol and low-density lipoprotein oxidation in normocholesterolemic and mildly hypercholesterolemic subjects. Nutr. Res. 25, 743-753. Available at: https://doi.org/10.1016/j.nutres.2005.08.004.

Irionodo-Dehond, M., Miguel, E., Castillo, M.D., 2018. Food byproducts as a sustainable ingredients for innovative and healthy dairy foods. Nutr. 10, 1358. Available at: https://doi.org/10.3390/nu10101358.

Jalili, M., Ehsani, R.M., Mazloumi, T.M., 2017. Evaluation of iron-fortified Feta cheese for physicichemical and sensory properties. Int. J. Dairy Technol. 70, 526-532. Available at: https://doi.org/10.1111/1471-0307.12378.

Kolakowski, P., Ozimkiewich, M., 2012. Restoration of kéfir grains subjected to different treatments. Int. J. Dairy Technol. 65, 140-145. Available at: https://doi.org/10.1111/j.1471-0307.2011.00746.x.

Kotilainen, L., Rajalahti, R., Ragasa, C., Pehu, E., 2006. Health enhancing foods: Opportunities for strengthening the sector in developing countries. Agriculture and Rural Development Discussion Paper 30.

Kök-Tas, T., Guzel-Seydim, Z., 2010. Determination of effects of using fat replacers and probiotic on ayran quality. Gida 35, 105-111 (in Turkish).

Kratz, M., Baars, T., Guyenet, S., 2013. The relationship between high-fat dairy consumption and obesity, cardiovascular, and metabolic disease. Eur. J. Nutr. 52, 124. Available at: https://doi.org/10.1007/s00394-012-04181.

Kruger M.C., Schollum, L.M., Kuhn-Sherlock B., Hestiantoro, A., Wijanto, P., Li-Yu, J., Agdeppa, I., Todd J.M., Eastell, R., 2010. The effect of a fortified milk drink on vitamin D status and bone turn over in post-menopausal women from South East Asia. Bone 46, 759-767. Available at: https://doi.org/10.1016/j.bone.2009.10.036.

Lopez-Exposito, I., Miralles, B., Amigo, B., HernandezLedesma, B., 2016. Health effects of cheese with focus on bioactive peptides, in: Frias, J., Martinez-Villaluenga, C., Penas, E., (Eds.), Fermented foods in health and disease prevention. Academic press, Elsevier,.239-273. Available at: https://doi.org/10.1016/B978-0-12-802309-9.00011-X.

Marco, M., Heeny, D., Binda S., Ciffeli, C., Cotter, P., Foligne, B., Ganzle, M., Kort, R., Pasin, G., Pihlanto, A., Smid E., Hutkins, R. 2017. Health benefits of fermented foods: microbiota and beyond. Curr. Opin. Biotechnolog. 44, 94102. Available at: https://doi.org/10.1016/j.copbio.2016.11.010.

Marsh, A., Hill, C., Paul Ross, R., Cotter, P., 2014. Fermented beverages with health-promoting potential: past and future perspectives. Trends Food Sci. Technol. 38, 113-124. Available at: https://doi.org/10.1016/j.tifs.2014.05.002.

Marsh, A.J., O’Sullivan, O., Hill, C., Ross, R.P., Cotter, P.D., 2013. Sequencing-based analysis of the bacterial and fungal composition of kefir grains and milks from multiple sources. PLoS ONE, 8. Available at: https://doi.org/10.1371/journal.pone.0069371.

Menrad, K., 2003. Market and marketing of functional food in Europe. J. Food Eng. 56, 181-188. Available at: https://doi.org/10.1016/S0260-8774(02)00247-9.

Mensink, R.P., Ebbing, S., Lindhout, M., Plat, J., Van Heugten, M.M.A., 2002. Effects of plant stanol esters supplied in low fat yoghurt on serum lipids and lipoproteins, noncholesterol sterols and fat soluble antioxidant concentrations. Atherosclerosis 160, 205-213.

Mitsukuchi, C., Kumagai, Y., Yasutomo, H., Ito, Y., Kitagawa, M., Fujiki, K., Tokudome, Y., 2017. Effects of folic acidfortified milk consumption on serum folate levels in Japanese female students: a randomized controlled trial stratified by methylenetetrahydrofolate reductase C677T 
genetic polymorphism. Vitam. Miner. 6, 170. Available at: https://doi.org/10.4172/2376-1318.1000170.

Mohanty, D.P., Mohapatra, S., Misra, S., Sahu, P.S., 2016. Milk derived bioactive peptides and their impact on human health - a review. Saudi J. Biol. Sci. 23, 577-583. Available at: https://doi.org/10.1016/j.sjbs.2015.06.005.

Nielsen, B., Candan Gurakan, G., Unlu, G., 2014. Kefir: a multifaceted fermented dairy product. Probiotics Antimicro. Prot. 6, 123-135. Available at: https://doi.org/10.1007/s12602-014-9168-0.

Najgebauer-Lejko, D., Sady, M., 2015. Estimation of the antioxidant activity of the commercially available fermented milks. Acta Sci. Pol. Technol. Aliment. 14 (4), 387-396. Available at: https://doi.org/10.17306/J.AFS.2015.4.38

Ocak, E., Rajendram, R., 2013. Fortification of milk with mineral elements, in: Preedy, V., Srirajaskanthan, R., Patel, V. (Eds.), Handbook of food fortification and health. From concepts to public health applications. Humana press, Springer Science + media business, New York, pp: 213-224. Available at: https://doi.org/10.1007/978-1-46147076-2.

Oliveira, R.P.S, Florence, A.C.R., Silva, R.C., Perego, P., Converti, A., Gioielli, L.A., Oliveira, M. N., 2009. Effect of different prebiotics on the fermentation kinetics, probiotic survaival and fatty acids profiles in nonfat symbiotic fermented milk. Int. J. Food Micro. 128, 467472. Available at: https://doi.org/10.1016/j.ijfoodmicro.2008.10.012.

Ortiz, Y., García-Amézquita, E., Acosta, C.H., Sepúlveda, D.R., 2017. Functional Dairy Products, in: Barbosa-Cánovas, G. et al. (Eds), Global Food Security and Wellness. Springer, New York, pp: 67-103. Available at: https://doi.org/10.1007/978-1-4939-6496-3_5.

Playne, M., Bennett, L.E., Smithers, G.W., 2003. Functional dairy foods and ingredients. Aust. J. Dairy Technol. 58, 242-264.

Prentice, A.M., 2014. First global summit on the health benefits of yogurt. Dairy products in global health. Am. J. Clin. Nutr. 99, 1212S-1216S.

Pereira, K., Guedes, J., Concalves, M., Loureiro, L., Castro, L., Geros, H., odrigues, L., Corte-Real, M., 2016. Lactoferrin selectively triggers apoptosis in hignly metastatic breast cancer cells through inhibition of plasmallemmal V-H+ATPase. Oncotarget. 7, 62144-62158. Available at: https://doi.org/10.18632/oncotarget.11394.

Petreska Ivanovska, T., Mladenovska, K., Zhivikj, Z., Jurhar Pavlova, M., Gjurovski, I., Ristoski, T., PetrushevskaTozi, L., 2017. Synbiotic loaded chitosan-Ca-alginate microparticles reduces inflammation in the TNBS model of rat colitis. Int. J. Pharm. 527, 126-134. Available at: https://doi.org/10.1016/j.ijpharm.2017.05.049.

Petreska Ivanovska, T., Zhivikj, Z., Bogdanovska, L., Mladenovska, K., Petrusevska-Tozi, L., 2018. Application of Lactobacillus casei 01 and oligofructose-enriched inulin in ayran. Maced. J. Chem. Chem. Eng. 37, 43-52. Available at: https://doi.org/10.20450/mjcce.2018.1287.

Rajaksekaran, A., Kalaivani, M., 2013. Desighner food and their benefits: A review. J. Food Sci. Technol. 50, 1-16. Available at: https://doi.org/10.1007/s13197-012-0726-8.

Ranadheera, R.D.C.S., Baines, S.K., Adams, M.C., 2010. Importance of food in probiotic efficacy. Food Res. Int. 43, 1-7. Available at: https://doi.org/10.1016/j.foodres.2009.09.009.

Sachdeva, B., Arora, S., Kaushik, R., 2014. Heat stability and thermal properties of calcium fortified milk. Cyta Journal of food, 13, 305-311. Available at: https://doi.org/10.1080/19476337.2014.971346.

Savaiano, D.A., 2014. First global summit on the health benefits of yogurt: lactose digestion from yogurt: mechanism and relevance. Am. J. Clin. Nutr. 99, 1251S-1255S.

Sayon-Orea, C., Bes-Restrollo, M., Marti, A., Pimnta, A.M., Martin-Calvo, N., Martinez-Gonzales, M.A., 2015. Association between yogurt consumption and the risk of metabolic syndrome over six years in the SUN study. BMC Public Health 15:170.

Sazawal S., Dhingra, U., Dhingra P., Hiremath, G., Sarkar, A., Dutta, A., Menon, V.P., Black R.E., 2010. Micronutrient fortified milk improves iron status, anemia and growth among children 1-4 years old: a double masked, randomized, controlled trial. PLoS one 5(8): e12167. Available at: https://doi.org/10.1371/journal.pone.0012167.

Simsek, S., Sanchez-Rivera, L., Nehir El, S., Karakaya, S., Recio, I., 2017. Characterisation of in vitro gastrointestinal digests from low caprine kefir enriched with inulin. J. Dairy Sci. 75, 68-74. Available at: https://doi.org/10.1016/j.idairyj.2017.07.004.

Summer, A., Formaggioni, P., Franceschi, P., Frangia, F., Righi, F., Malacarne, M., 2017. Cheese as functional food: The example of Parmigiano Reggiano and Grana Padano. Food Technol. Biotechnol. 55, 277-289. Available at: https://doi.org/10.17113/ftb.55.03.17.5233.

Sharafedtinov, K.K., Plotnikova, A., Alexeeva, R.I., 2013. Hypocaloric diet supplemented with probiotic cheese improves body mass index and blood pressure indices of obese-hypertensive patients- a randomized double-blind placebo controlled pilot study. Nutr. J. 12, 138. Available at: https://doi.org/10.1186/1475-2891-12-138.

Sabatier, M., Egli, I., Hurrel, R., Hoppler, M., Gysler, C., Georgeon, S., Mukherje, R., Richon, P.A., Vigo, M., Foman, J.T., Zeder, C., Schaffer-Leguart, C., 2017. Iron bioavailability form fresh cheese fortified with iron enriched yeast. Eur. J. Nutr. 56, 1551-1560. Available at: https://doi.org/10.1007/s00394-016-1200-6.

Shiomi, M., Sasaki, K., Murofushi, M., Aibara, K., 1982. Antitumor activity in mice of orally administered polysaccharide from kefir grain. Jpn. J. Med. Sci. Biol. 35, 75-80.

Singh, V.P., Sachan, N., 2011. Nutraceutical properties of milk and milk products. Am. J. Food Technol. 6, 864-869. Available at: https://doi.org/10.3923/ajft.2011.864.869.

Siro, I., Kapolna, E., Kapolna, B., Lugasi, A., 2008. Functional food. Product development, marketing and consumer acceptance - a review. Appetite 51, 456-467. Available at: https://doi.org/10.1016/j.appet.2008.05.060.

Soukoulis, C., Fisk, I.D., Bohn, T., 2014. Ice cream as a vehicle for incorporating health-promoting ingredients: conceptualization and overview of quality and storage stability. Comp. Rev. Food Sci. Food Saf. 13, 627-655. Available at: https://doi.org/10.1111/1541-4337.12083.

Tippets, M., Martini, S., Brothersen, C., McManon, D.J., 2012. Fortification of cheese with vitamin D3 using dairy protein emulsions as delivery systems. J. Dairy Sci. 95, 4768-4774. Available at: https://doi.org/10.3168/jds.20115134. 
TFC, 2009. Turkish Food Codex, Fermented Milk Products, Turkish Food Codex Regulations. Regulation no: 2009/25. Republic of Turkey Ministry of Food, Agriculture and Livestock, Ankara, Turkey.

Turkmen, N., Akal, C., Ozer, B., 2019. Probiotic dairy-based beverages: A review. J. Funct. Foods 53, 62-75. Available at: https://doi.org/10.1016/j.jff.2018.12.004.

Van der Hee R.M., Miret, S., Slettenaar, M. Duchateau G.S., Rietveld, A.G., Wilkinson J.E., Quail, P.J., Berry, M.J., Dainty, J.R., Teucher, B., Fairwether-Tait, S.J., 2009. Calcium absorbtion from fortified ice cream formulations compared with calcium absorption from milk. J. Am. Diet. Assoc. 109, 830-835. Available at: https://doi.org/10.1016/j.jada.2009.02.017.

Visioli, F., Strata, A., 2014. Milk, Dairy products and their functional effects in human: a narrative review of recent evidence. Adv. Nutr. 5, 131-143. Available at: https://doi.org/10.3945/an.113.005025.

Volpe, R., Niittynen, L., Korpela, R., Sirtori, C., Bucci, A., Fraone, N., Pazzucconi, F., 2001. Effects of yoghurt enriched with plant sterols on serum lipids in patients with moderate hypercholesterolaemia. Br. J. Nutr. 86, 233-239.
Vujicic, I., Vulic, M., Konyves, T., 1992. Assimilation of cholesterol in milk by kefir cultures. Biotechnol. Lett. 14, 847-850. Available at: https://doi.org/10.1007/BF01029151.

Xie, N., Zhou, T., Li, B., 2012. Kefir yeast enhance probiotic potentials of Lactobacillus paracasei H9: the positive effects of congregation between the two strains. Food Res. Int. 45, 394-401. Available at: https://doi.org/10.1016/j.foodres.2011.10.045.

Yang, Z., Zhou, F., Ji, B., Li, B., Luo, Y., Yang, L., Li, T., 2010. Symbiosis between microorganisms from kombuha and kefir: potential significance of to the enhancement of kombuha function. Appl. Biochem. Biotechnol. 160, 446455. Available at: https://doi.org/10.1007/s12010-0088361-6.

Yilmaz, M.T., Dertil, O., Toker, S., Tatlisu, N.B., Sagdic, O., Arici, M., 2015. Effect on in situ exopolysaccharide production on physicochemical, rheological, sensory, and microstructural properties of ayran: an optimization study based on fermentation kinetics. J. Dairy Sci. 98, 1604-1624. Available at: https://doi.org/10.3168/jds.2014-8936.

\title{
Концепти, придобивки и идни трендови на функционални млечни производи
}

\author{
Лилјана Анастасова ${ }^{1 *}$, Тања Петреска Ивановска ${ }^{2}$, Руменка Петковска ${ }^{1}$, \\ Лидија Петрушевска-Този
}

\author{
${ }^{1}$ Институт за применета хемија и фармащевтски анализи, Фармацевтски факултет, \\ Универзитет „Св. Кирил и Методиј“, 1000 Скопје, Република Македонија \\ ${ }^{2}$ Институт за применета биохемија, Фармацевтски факултет, \\ Универзитет „Св. Кирил и Методиј“, 1000 Скопје, Република Македонија
}

Клучни зборови: функционална храна, млеко, млечни производи

Зголемениот интерес на потрошувачите за здравствените придобивки поврзани со храната доведе до развој на таканаречените функционални прехранбени производи што овозможуваат подобрување на здравствената состојба на луѓето и намалување на трошоците за лекување.

Млекото и млечните производи се користат во исхраната илјадници години наназад и претставуваат извор на значајни хранливи состојки како што се протеини, масти и калциум. Покрај високата хранлива вредност, тие покажуваат и поволни физиолошки својства, па развојот на функционални млечни производи претставува еден од најбрзо растечките сегменти во млечната индустрија, како и еден од најголемите сектори на глобалниот пазар на функционални производи.

Во овој труд е даден краток осврт на здравствените придобивки, природната функционалност на млечните производи, како и предизвиците и идните трендови во развојот на функционалните млечни производи како системи за испорака на биоактивни супстанции. 
